\title{
Coaching placements and incidental learning - how reflection and experiential learning can help bridge the industry skills gap
}

\author{
Name \\ Philippe Crisp, University of Chichester, UK
}

\section{Abstract}

In the fields of sports coaching and higher education, there are significant implications related to the delivery and effectiveness of work-based learning (WBL), learning styles and occupational competency. Alongside this, similar claims are made throughout the academic and policy literature in both fields about the effectiveness and necessity of improving issues of skill development and employability (see SkillsActive, 2010a; SkillsActive, 2010b; Taylor and Garratt, 2010; Pegg et al., 2012). This paper therefore examines, in the context of the sports coaching industry's relevant skills gaps, the learning experiences of a level five cohort who undertook supported coaching placements as part of a placement module. Using two focus groups ( $\mathrm{N}=15$ and $\mathrm{N}=13$ respectively) the findings demonstrate that it is not only preferential, from the students' perspective, to engage in WBL but that the coaching placements also helped the students meet many of the wider professional sector's identified skills gaps. The findings also indicated that it is the student-coaches' learning through incidental learning (unintentional, yet through the planned placements) that most significantly determined their professional competency.

Keywords: Formative learning; employability; sports coaching; experiential learning; professionalism; incidental learning.

\section{Introduction}

There is a current focus within broader policy domains on the development of work-based skills. In the case of sports coaching, the higher education (HE) sector, SkillsActive (the sector skills council for active leisure, learning and well-being) and UK Coaching 
(previously SportsCoachUK [scUK], the advisory body for sports coaching in the UK) are all seeking to create a framework of qualifications, support systems, and endorsement processes that will address what are considered to be significant skills gaps in sports coaching. Whilst at first glance these sectors may seem to be independent of each other, the reality is that there is a necessary convergence in their approaches to understanding the issues surrounding sports coaching as a vocation - principally those issues related to what are considered to be significant skills gaps and approaches to professionalism. Indeed the central premise of all three sectors, relating to the development of more skilled coaches, is one that is concerned with addressing these issues. It is unsurprising, therefore, that they must work in tandem to address any perceived shortcomings and skills gaps and develop approaches that are complimentary in nature. As a direct consequence of this complimentary approach the use of work-based learning (WBL) is often considered germane to the development of coach education and provision within the HE sector (Driska and Gould, 2014; Palermo et al., 2015; Kovacs and Corrie, 2017). Much of WBL is concerned with using reflective practice in order to improve working habits and capacity for reflective working (Cox, 2005; Hafford-Letchfield and Bourn, 2011) and it is in this context that this paper is interested.

When considering the implications of WBL, one area that requires further examination is the differing contexts within which people learn to coach. Of particular note here is the difference between the types of coach learning that people undertake in work-like, volunteer or vocational strands of sports coaching compared to those of students on coaching related HE courses (student-coaches, as this paper calls them). For the former, reflection in coaching and the use of formal, informal, and non-formal methods of coach education (to be discussed in more detail later in the paper) usually refer to multiple or perhaps single learning opportunities. These learning opportunities are conventional and occur frequently for coaches (again, coaches operating under work-like, volunteer, or vocational strands) as opposed to student-coaches. A key difference then is that studentcoaches are involved in learning through longer durations (perhaps a week, a month, a semester, a year, or even a day) and that they are also - and often - learning to operate within new professional conventions in relation to professional practice and undertaking work-like responsibilities. 
Hence, whilst acknowledging that there is a broad body of work explaining the use of reflection and bridging skills gaps, this paper seeks to broaden the discourse related to coach education by presenting evidence of how student-coaches can learn with and through others. It does this in three ways: (1) by analysing the way in which studentcoaches feel that they can benefit from WBL; (2) by matching how wider ideas of skills gaps within the coaching sector might be prevented through the use of WBL; (3) through extending existing theoretical approaches within coaching that use the idea of formal, informal, and non-formal coach education, to also using the concept of incidental learning, one that is recognised more in organisational and managerial development. In sum then, the focus of the paper is to explore the best methods for teaching and learning how to coach within the context of WBL.

The way the paper is organised is first to define employability and detail government policy on widening participation and the creation of extended educational opportunities.

Secondly, to outline the structure of UK coaching practice and thirdly, to present a section outlining coach learning, reflective practice, and work placements. The paper then details the methodology that the study undertook before finally undertaking an analysis and discussion of the data.

\section{Background and rationale - employability}

The term employability itself, whilst not necessarily contested, is certainly capable of illustrating different theoretical perspectives. Basic examples of this range from understanding how someone can gain and maintain work, to the process of readying oneself for work over a period of time. It can also be conceptualised through what might be considered a reciprocal relationship through employers and employees (Minten and Foster, 2009). Yet it is often referred to in terms of political will and capital, with direct references and links to broader economic productivity.

At time of writing, government policy in the UK regarding the provision of a more skillbased economy insists upon employer engagement within the decision making process for developing and/or choosing which skills or professional standards suit different job sectors (BIS, 2010; QAA, 2014; OFFA, 2015). In relation to this and from the perspective of $H E$, the issue of employability was highlighted as long ago as the Robbins report (Lord 
Robbins, 1963). Also of particular note is that as recent as the latter part of the 1990's, the Kennedy report 'Learning Works' (1997) established the notion that learning should be placed at the centre of the economic and social policy systems within the UK. The rationale that emerged from this report sought to re-establish Britain within the changing economic global context through addressing gaps highlighted within skills audits. In addition to this, somewhat more recently there was also a growing realisation of a need to develop a work force containing more workers with graduate skills in order to enhance the nation's qualification base (Maher, 2005). The HE sector recognised this perceived necessity for greater employability, and indeed, the Higher Education Academy commissioned the Enhancing Student Employability Coordination Team (ESECT) and published the 'Pedagogy for employability' report (ESECT, 2006) to outline best practice in embedding employability and the political context and pressures on HE.

Several themes presently underscore what we understand as employability in the HE sector. Some of these are consistent, such as the fact that graduates are expected to possess substantive knowledge, intellectual/critical attributes and a range of skills to reflect the workplace (Gibbs, 2012; Ford et al., 2015). This, however, presents problems in terms of the sheer amount of information, teaching and learning that needs to take place to meet these expectations, expectations that, in essence, need to bridge both the academic and vocational worlds. Inevitably, the process of embedding employability through the HE system needs to be current, relevant and reflect the occupation/sector within which students seek to study and then, in all likelihood, seek work within after graduation. In order to meet this combination of work-based understanding and academic requirements, providers often use a holistic educational approach that incorporates both skill training and transferable, higher cognitive, attributes (Deeley, 2014; Higher Education Academy, 2016).

Yet while it is true that the HE sector continues to endeavour to develop more skills and address the issue of increasing employability for their students in response to these demands, currently it is also fair to say that there are also additional pressures on the HE system. These pressures exist because of austerity measures, low economic growth and higher tuition fees (Massey, 2010; Pegg et al., 2012; Student Funding Panel, 2015).

Indeed, the complexity of addressing employability through the HE system is now, effectively, underlined by the 2010-2015 coalition government's re-structuring of the 
method through which HE is funded following Lord Browne's recommendations in the independent 'Securing a sustainable future for higher education' report (Browne, 2010) and the subsequent white paper 'Higher education: students at the heart of the system' (BIS, 2011). The recommendations related to the funding of HE in these papers have resulted in what many consider to be the development of a more result-oriented, marketled and functionalist oriented system and attitude to education. As a consequence of this there are moves within the HE sector to be more pro-active in developing courses that meet national policy objectives whilst simultaneously providing additionality (for example, bolt-on courses or extended placement links) and value for money. In fact Gibbs (2012), in his report for the Higher Education Academy (HEA) entitled 'Implications of dimensions of quality in a market environment', specifically explores the nature of quality, provision and satisfaction of HE courses that students - and more importantly in many respects for the future HE landscape, prospective students - would like. In sum then, as a result of all of the pressures resulting from the restructuring of HE's government funding, many $\mathrm{HE}$ institutions have looked to directly embed elements within their programmes that demonstrate the concept of employability.

Underpinning this emphasis on developing employability is the broader policy context of widening participation. Widening participation is generally considered to be an approach that signifies a broader political agenda, being concerned with notions of allowing more people from under-represented groups to participate in learning - principally those who would not have normally considered HE. More specifically, additional policy directives of the concept of widening participation were intended to develop a more diverse student and academic body for Britain (DfES, 2003). This policy context continues to this day, with both the 'National strategy for access and student success' (HEFCE and OFFA, 2015) and the 2016 white paper 'Success as a knowledge economy: teaching excellence, social mobility and student choice' (BIS, 2016) demonstrating continued government commitment alongside a significant investment in the new higher and degree apprenticeship schemes (Universities UK, 2017). As a consequence of this, when we consider the policy context within which widening participation operates in, it can be said that it has distinct strands within both the further education (FE) and HE sector (DfE, 2017). Underpinning how it works in the two sectors, however, are the aforementioned commonalities of the benefits and advantages of a 'learning society' (Kennedy, 1997). 


\section{UK coaching practice and structure}

Currently, the United Kingdom Coaching Certificate (UKCC) has shaped contemporary approaches to coaching practice. This is effectively an endorsement process that quality assures NGB coaching awards and sets out criteria that assists with standardisation and coherency. This UKCC model looks to conceptualise, chart and offer a pathway to improve coaching expertise. More particularly it complements National Vocational Qualification (NVQ) and National Occupational Standards (NOS) competency-based criteria (Taylor and Garratt, 2008; Taylor and Garratt, 2010). NVQs are practical, competency-assessed qualifications that assess underpinning knowledge and skills. They are calibrated against the first five levels of the National Qualifications Framework (NQF) which recognises the level of qualification within England, Wales, and Northern Ireland (GOV.UK, 2016). In the same way, NOS are also used to demonstrate underpinning knowledge and to describe what individuals need to know and do to carry out specific job roles and functions. What is of particular note here is that the knowledge necessary to pass NVQs is developed by the awarding bodies and the sector skills councils who determine the content and outcomes of qualifications through the NOS themselves (National Occupational Standards, 2016).

In effect, this means that passing the NOS demonstrates vocational competency. In much the same way, the UKCC model corresponds to the principles of the NOS and as such is an example of a system that measures proficiency through a competency aligned framework. With respect to the nature and function of coaching awards there is also the scUK $4 \times 4$ model that acknowledges different coaching contexts. More specifically, this model conceptualises the domains of coaching in the following populations and respective coach roles: children's, participation, performance and elite sectors. Whilst not a qualification framework per se, the scUK model serves to inform both wider coaching literature and understanding, as well as the on-going development of coaching awards. In summary, these models currently reflect the desire to modernise coaching that has been expressed by both the Conservative and Labour governments over the past 30 years through professionalisation (Green and Houlihan, 2005).

Yet, despite the creation and promotion of these frameworks for understanding sports coaching, there are still significant skills gaps identified within the UK for the coaching sector (as part of SkillsActive's broader five subsector remit). These include: team working; 
communication; technical and practical skills; sport specific skills and problem solving (SkillsActive, 2009; SkillsActive, 2010a; SkillsActive, 2010b). Furthermore, within SkillsActive's 'Skills priorities for active leisure, learning and well-being: UK summary' (2009) report, the specific skill gaps within the technical areas of the sport sector (coaching) included initiative and planning. One area that could perhaps additionally be considered to be of particular importance to employers in the sports coaching industry is the nature of soft skills, more specifically in the area of inter and intrapersonal skills.

This is already an area that UK Coaching (scUK, 2011) highlights as critical in participation and youth coaching, which from the vocational perspective can be evidenced by the fact that instructor and participant relationships were considered to be a "key driver in achieving participation" by SkillsActive (2009, p.13). Moreover, the UK Commission for Employment and Skills (UKCES) stated that "communication skills over technical or practical skills" were considered most important for employers (UKCES, 2012, p.50). Consequently, and in recognition of these vocational sector demands, it might be argued that new approaches to embedding required skills in HE institution sport courses are necessary to meet what is a clear, vocationally relevant and industry-led demand.

\section{The work placement approach to incorporating: employability, higher education and coaching practice}

Alongside the call from the workplace for more work specific competencies, there is now the endorsement of foundation degree and undergraduate courses in sports coaching education led by SkillsActive, UK Coaching and the Institute for the Management of Sports and Physical Activity (IMSPA). This calls for demonstrable evidence of not less than 100 (foundation degree) or 150 (undergraduate degree) hours of coaching practice (scUK, 2009; SkillsActive, 2018). Ideally, according to UK Coaching, supported coaching placements and the opportunity for experiential learning to take place should be considered by HE institutions in this context of meeting their proposed endorsement process. Because of the significance of this it is not unreasonable to assume that supported work placements will, by necessity, become a more frequently used method of assessment and learning within what many envisage as an emerging convergence between $\mathrm{HE}$ and the workplace. 
Given the potential differences that supported coaching placements may present in contrast to more traditional 'classroom' based pedagogy, it is unsurprising that types of learning must be considered when developing best practice for students to bridge the gap between HE and employment. Thus this research aims to present - in the context of learning theories associated with coach education - a brief analysis of the major themes and arguments relating to the development of effective learning and relevant vocational competencies that a sports coach is expected to possess.

First, given the fact that the context of this paper is based on student-coaches and the best methods for teaching and learning how to coach, it is worth outlining the differences between a teacher (PE) and a coach. Similar patterns of complexity and delivery are evident among both teaching and coaching (Lyle, 2002; Jones, 2006). While both look to improve and enhance specific patterns of learning, fundamental differences are nevertheless evident in the way that they: (a) focus on educational or specialist knowledge with teaching (certainly PE) being seen more as the overall development of the individual, and coaching more as the training and the development of physical skills; (b) the way that they differ in the journey to professional status and qualifications (with teaching taking approximately five years and coaching, at entry level, no more than a few weeks at times). Yet, despite these divisions, it is also true that any divide between perceptions of sports coaching and teaching needs to take into account the similarities that exist - in education, teaching, communicating, maintaining positive relationships and how they learn.

When considering how coaches learn best, it is worth nothing that central to the idea of coach education is the schema related to sources of coach development and knowledge that Cushion et al. (2010) propose. The terms used here are formal coach education, informal coach learning and non-formal coach learning. The first, formal coach education, is principally concerned with the delivery of national governing body awards and official accreditation. As such, this method and source of learning is structured, organised, accredited, assessed and directed. In contrast, informal coach learning is self-directed and uses a range of sources. Accordingly, this type of learning is relatively unstructured, nonaccredited and non-assessed. The last learning source that Cushion et al. (2010) propose, non-formal coach learning, incorporates a variety of methods such as workshops, small courses and general continuous professional development (CPD). By nature, much of this takes place outside of governing body systems and whilst it can indeed be structured and mediated, it is often self-directed. In reviewing the comparative effectiveness of all three 
fields, current literature (e.g. Irwin et al., 2004; Jones at al., 2004; Gilbert and Trudel, 2006; Cushion et al., 2010) suggests that in the domain of adult learning it is informal learning that has a greater impact and importance on the development of coaching practice than that of formal coach education. A good example of this can be found in Gilbert and Trudel's (2001) multiple case study of six youth sport coaches. This study found that coaches learn by reflecting on practical coaching experience; hence, both reflection and experience are characterised by them as essential elements of coach education.

Given the significance of this, it is worth noting just how important the use of reflection and critically appraising one's own performance is and why it is considered to be so important for developing coaching practice. As an example of this, the work of Gilbert et al. (2006), for instance, illustrates the way in which formal and non-formal coaching courses can be seen to hold less value to a coach's perceived development than everyday coaching experiences. In sum then, it might be said that a particularly important feature of this brief summary of literature is the fact that reflective practice could conceptually connect coach education, theory, and the practice of coaching itself. Knowles' (2005) work, for example, suggests that the use of reflective practice should be inherent within coaching curriculums in order to capitalise coach knowledge and learning.

It is in respect of the above viewpoint that the emerging recognition of reflective practice as an instrument in developing practice has taken place. Yet critical to the understanding of the importance and capital that reflective practice has in sports coaching education is the concept of professionalism. From what might be considered a somewhat basic level, our understanding of the essence of what may be termed 'professionalism' can potentially be seen through the work of Schön $(1983 ; 1987)$ who saw those capable of utilising technical rationality as:

...instrumental problem solvers who select technical means best suited to particular purposes (Schön, 1987, p.3).

Schön additionally saw the construct of professionalism as being couched in artistry, stating that:

...artistry is an exercise of intelligence (Schön, 1987, p.13) 
and that proficient professionals seem to possess a repertoire of skills, inherent abilities and competencies.

Perhaps of most relevance to those interested in the accumulation of knowledge through supported work placements is that Schön's work sees the ability to cycle "through an iteration of moves and appreciations" (1987, p.64) as enabling the development of a new form of inquiry into a multitude of possible outcomes, outcomes that can be read by those professionals who possess a:

...range of experiences and knowledge that they can apply to unfamiliar situations (Schön, 1987, p.68).

In effect, and to clarify his work, this knowledge/experience capital allows practitioners/ 'artists' to sequentially engage on a mental level with and through a range of different possibilities and hypotheses. Overall, and considering the implications and benefits of developing professionalism, it is unsurprising then that $\mathrm{HE}$ institutions are using reflective practice as a tool in developing the capabilities of their students - perhaps principally through work placements that, effectively, increase experience and the knowledge 'capital' of students.

Having outlined the literature related to the effectiveness of coach education and the importance of longer term engagement with the craft of coaching itself through developing reflective practice, it is interesting to note also the student perspective on assessments and developing competency through work-based training within HE. An example of this can be seen in Thurgate and MacGregor's (2009) work. This work analysed the perceptions of a number of health and social care students who undertook work placement training and their findings indicated that the cohort they used as their sample (16) placed a particular premium on how they felt experiential learning helped facilitate a positive effect in their learning. As Thurgate and MacGregor's (2009) study admittedly used health and social care as the domain in which they undertook their study, a more appropriate illustration of how sports coaching students might see work placement type assessments is through Turner and Nelson's (2009) work. Here, they undertook a study in which 10 graduate coaches reflected upon their experiences of an HE programme. What might be 
considered the most significant finding of this study was their assertion that person-centred theory should drive course content. However, an additional and very interesting element within the study was the fact that the graduate coaches felt that an element of their assessments should have had tutors "practically assess their coaching performance and provide specific feedback" (Turner and Nelson, 2009, p.15).

\section{Methodology}

The coaching placement module used for this study was developed with the intention of meeting broader WBL standards and, as such, involved a structured learning experience leading to completion of the module. The module has run in two different guises (due to revalidation and module code/title change) over a nine-year period and the results of this study reflect the 2014-15 delivery. In terms of delivery, the module participants needed to complete two assessments. The first was the submission of a logbook and reflective account and, the second, an assessment of a coaching session in a community or nonuniversity academic setting. Both assessment elements contributed $50 \%$ of the final mark for the module and the module itself ran for a full academic year. In terms of the practical assessment, the module participants were entitled to two visits from university staff, with the first visit being advisory and formative and the second visit summatively assessed.

All research process should be defined by choice (Crotty, 2004; Lynch, 2010). In this regard, the choice of research process for this study needed to be framed by how best to develop insight into the meanings and values that students attributed to their coaching placements. Considering that an interpretivist approach to research seeks to understand human behaviour and human realities, an interpretive research design underpinned this study and the qualitative methodological approach of using focus groups was used (Gratton and Jones, 2010). Advantages of using focus groups are twofold; first, that in accordance with an interpretivist approach to research, they can elicit underlying beliefs and attitudes. Secondly, by using a larger group instead of individual interviews, greater discussion and interaction can take place, potentially developing the depth and range of answers (Rubin and Rubin, 1995; Amis, 2005; Gratton and Jones, 2010).

Two focus groups were held with the students. The first, a more informal opportunity to discuss the strengths, weaknesses and any particular concerns that the students may 
have had regarding the module, was held after mid-way through the module (the module consisted of two semesters, so this was just past the half way point of the module). 15 out of the 20 cohort total were involved in this focus group, The second focus group took place at the midway point of the second semester, just past the three quarter point of the module delivery. This second focus group consisted of a short outline of learning styles, coach education and experiential learning - all elements that the students had previously covered through their degree programme. After this brief (10 minute) refresher session, the students were given time to discuss their preferential learning styles and their perceptions of the effectiveness of the module. With a group of 13 participating this time (all who had been in the initial group of 15 for the first focus group), they were split into four groups and given three areas to consider both individually and as a group: (a) their favourite type of learning; (b) the effectiveness of the advisory sessions and (c) the impact of the module on individuals' development. The groups used flipchart paper to construct mind maps, tables or bullet points of their responses to the broad questions outlined above. The students were encouraged to write down their individual comments and, in particular, to address their individual perceptions of the three areas outlined above and how they might wish to answer them. The essence of using group work to facilitate the session was to try and ensure a more constructive, productive series of answers. Feedback was also taken through notes made by the researcher who supported the group work and asked questions.

The above process meant that all of the information and everything that was said was written down in order that it might be transcribed. The results were then systematically decoded and categorised, which in turn allowed common patterns and themes to emerge and be made sense of. Such a methodological process was much the same as if individual interviews had been undertaken - in that the researcher sought to be able to present ideas that were indicative of/represented a number of responses. The categories that emerged during the first focus group were relatively easily classified into either positive or negative experiences that they had encountered. In the second focus group, the following categories emerged: experiential learning; tutor feedback; skills gaps and incidental learning. 


\section{Results/ Discussion}

\section{First focus group results}

\section{Figure 1. Focus group 1 results.}

\begin{tabular}{|l|l|}
\hline Positives & Negatives \\
\hline - Experience coaching in a different & - More coaching in university. \\
environment as opposed to course & - Frequency of action sets. \\
friends. & - Set up placements earlier. \\
- Easy to find placement if you didn't have & - Visits to placements before hand ins - \\
one. & same with action sets. \\
- Assessment easy to understand. & - Single assessment instead of multiple \\
- Put into practice what we have learnt. & assessments. \\
- Area of interest. & - Organisation - dates visit. \\
- Tutor feedback. & \\
- Opportunity to show our coaching & \\
philosophy. & \\
- Experience. & \\
- Explore other areas in sport & \\
environments. & \\
- Independent experience. & \\
\hline
\end{tabular}

As stated in the methodology section above, the first focus group was intended to act as an informal opportunity to discuss the strengths and weaknesses of the module. As can be seen from the results of the first focus group, the cohort felt that the module had a number of strengths which they felt directly benefited their coaching practice. Principally this came through in the responses that highlighted how a different coaching medium, outside of the university, developed experience. The negative elements to the module were considered to be, on the whole, concerned with elements of the teaching practice that were resource constrained - essentially those asking for more support through increased action set facilitation and a quicker commencement of the visits themselves. 


\section{Second focus group results}

\section{Figure 2. Focus group 2 results.}

\begin{tabular}{|c|c|c|c|}
\hline $\begin{array}{l}\text { Favourite type of } \\
\text { learning }\end{array}$ & $\begin{array}{l}\text { The effectiveness } \\
\text { of the advisory } \\
\text { sessions }\end{array}$ & $\begin{array}{l}\text { The impact of the } \\
\text { module on } \\
\text { individuals' } \\
\text { development }\end{array}$ & $\begin{array}{l}\text { ng about } \\
\text { ractice }\end{array}$ \\
\hline $\begin{array}{l}\text { - Visual. } \\
\text { - } \text { Demonstrations. } \\
\text { - } \text { Experving others. } \\
\text { with equipment. } \\
\text { - I'm allowed to lead } \\
\text { full sessions for } \\
\text { 1.5 hours and can } \\
\text { learn from } \\
\text { experience and } \\
\text { mistakes. } \\
\text { - Kinaesthetic. } \\
\text { - } \text { Learn by watching } \\
\text { participants (trial } \\
\text { - } \text { - Thd error). } \\
\text { - } \text { Taking notes. } \\
\text { they involved! let me do } \\
\text { and drills. } \\
\text { writing - developing plans. }\end{array}$ & $\begin{array}{l}\text { - Having an } \\
\text { observer } \\
\text { watching my } \\
\text { session and } \\
\text { going through it } \\
\text { with me helped } \\
\text { me know the } \\
\text { specific areas } \\
\text { where I need to } \\
\text { improve. } \\
\text { - Getting } \\
\text { formatively } \\
\text { assessed and } \\
\text { getting } \\
\text { feedback. } \\
\text { - Feedback on } \\
\text { areas to } \\
\text { improve. } \\
\text { - } \text { Help you give } \\
\text { feeding } \\
\text { yourself. } \\
\text { Self-analyst role. }\end{array}$ & $\begin{array}{l}\text { - The placements } \\
\text { all helped with } \\
\text { experience of } \\
\text { doing it on your } \\
\text { own and having } \\
\text { to plan to deliver } \\
\text { sessions } \\
\text { appropriate to the } \\
\text { participants. } \\
\text { Experienced } \\
\text { feedback. } \\
\text { Shows your key } \\
\text { areas of } \\
\text { improvement. } \\
\text { - Suggests } \\
\text { different ways to } \\
\text { improve. } \\
\text { seeing other } \\
\text { coaches- visual } \\
\text { and aiding } \\
\text { development. } \\
\text { sives you a } \\
\text { develop your } \\
\text { coaching. } \\
\text { Imple place to } \\
\text { - }\end{array}$ & $\begin{array}{l}\text { - Didn't have a } \\
\text { choice about } \\
\text { turning up on } \\
\text { time - they did, } \\
\text { so I knew I had } \\
\text { to. } \\
\text { - I thought about } \\
\text { how I need to } \\
\text { present myself to } \\
\text { people not from } \\
\text { university. } \\
\text { I learnt that I } \\
\text { need to be } \\
\text { punctual, arrive } \\
\text { early, finish late. } \\
\text { Customer } \\
\text { services and } \\
\text { having people } \\
\text { depend on me - } \\
\text { something the } \\
\text { other coaches } \\
\text { and staff would } \\
\text { do! } \\
\text { good thing - I } \\
\text { porced to work } \\
\text { ith others, a } \\
\text { - }\end{array}$ \\
\hline
\end{tabular}




\begin{tabular}{|c|c|c|c|}
\hline $\begin{array}{l}\text { - Learning by doing. } \\
\text { - Learning while } \\
\text { coaching. } \\
\text { Improving } \\
\text { coaching skills. } \\
\text { - Sessions more } \\
\text { practical. } \\
\text { Allows for } \\
\text { experimentation. } \\
\text { As someone who } \\
\text { learns from } \\
\text { reading and } \\
\text { writing it is still } \\
\text { effective for me } \\
\text { when it comes to } \\
\text { planning - I love } \\
\text { the development. } \\
\text { Even as a visual } \\
\text { learner, I get the } \\
\text { wapportunity to } \\
\text { watch others. }\end{array}$ & $\begin{array}{l}\text { - Realising } \\
\text { strengths and } \\
\text { weaknesses. } \\
\text { - Learn from each } \\
\text { other. } \\
\text { - Marks and } \\
\text { feedback let me } \\
\text { know where I } \\
\text { actually am. } \\
\text { It's really } \\
\text { important to } \\
\text { have your } \\
\text { lecturers come } \\
\text { and chat with } \\
\text { you - they're the } \\
\text { experts and, at } \\
\text { the least, we } \\
\text { want to learn } \\
\text { from them. }\end{array}$ & $\begin{array}{l}\text { confidence and } \\
\text { personality. } \\
\text { Helps you learn } \\
\text { coaching specific } \\
\text { skills and } \\
\text { legislation e.g. } \\
\text { equality and child } \\
\text { protection. } \\
\text { Experiment with } \\
\text { coaching styles. } \\
\text { Focuses your } \\
\text { mind on the task } \\
\text { at hand. } \\
\text { The only way to } \\
\text { really learn - } \\
\text { doing it. } \\
\text { They (the } \\
\text { formative } \\
\text { assessments) are } \\
\text { good because } \\
\text { you get like key } \\
\text { points, even if it } \\
\text { is little things like } \\
\text { what you're } \\
\text { wearing. Even } \\
\text { things like that } \\
\text { can help, not just } \\
\text { but in general to } \\
\text { be grional. }\end{array}$ & $\begin{array}{l}\text { really good } \\
\text { habits. } \\
\text { - Best way to learn } \\
\text { was to hang out } \\
\text { with people who } \\
\text { do this kind of } \\
\text { thing - not just } \\
\text { students. } \\
\text { I can't believe } \\
\text { how many little } \\
\text { things I picked up } \\
\text { from others I was } \\
\text { working with, } \\
\text { when to get } \\
\text { equipment, how } \\
\text { to act with others, } \\
\text { how to speak to } \\
\text { parents. } \\
\text { I think it's been } \\
\text { the best } \\
\text { experience for } \\
\text { me to really } \\
\text { teach me about } \\
\text { the real world. }\end{array}$ \\
\hline
\end{tabular}




\section{Experiential learning and tutor feedback}

The kind of responses generated by the second focus group illustrated that the cohort valued how the module had enabled them to use a range of learning styles. Interestingly, whilst their comments such as how they could "experiment" and "get involved" often related to how they could either benefit from a more kinaesthetic type of learning, they also alluded to how other methods of learning were facilitated. Of most relevance perhaps is the fact that "watching others" in other environments was considered to be an effective element of the experiential approach. Whilst the author acknowledges that the term learning styles is contested, with some pointing out that they are representative of a highly complex system of teaching and learning and that they can change over time, experience, and context (LSRC, 2004), it is interesting to note that these reflections and interpretations of individual learning styles echo the essence of what experiential learning should endeavour to do. This is to give a wide learning experience that enables the students to use their preferred learning styles and, in this instance, also allow for peers to support and learn from each other (Byl et al., 2015). In short, experiential learning, as advocated by Schön (1987) and other researchers such as Groves et al. (2010) and Shepherd (2006), advocates a philosophy whereby the learning process is underpinned by significant personal reflection and consequently the personal construction of knowledge.

This kind of interpretation, one that sees the use of experiential learning as key to developing competency, can be applied to the results of both focus groups. Really, the findings indicated consistency between how the students regarded the construction of their knowledge. For example, when a participant in the first focus group said that the issue of experiencing coaching in a different environment to one which had course 'friends' on was important, all of the participants made comments indicating that they were in agreement. In fact, the majority of participants felt that the opportunity to show their coaching philosophy was important to promote independent thinking. As an example, one participant in the first focus group added that the placements allowed them to "put into practice what we have learnt".

Indeed, when the results of both focus groups are taken into consideration it would be fair to say that the participants agreed on the following; that the combination of independent experience and tutor feedback facilitated through the modules were key to developing the students' knowledge and understanding of coaching practice. Encouragingly, all the 
student-coaches seemed aware of the benefits of working with tutors, with one explaining that "it's really important to have your lecturers come and chat with you - they're the experts and, at the least, we want to learn from them". These findings concur with Turner and Nelson's (2009) work which advocated that more tutors should practically assess coaching performance.

\section{Skills gaps and incidental learning}

While there was a noticeable similarity in the responses of the majority of the research participants in regards to how their experiences of the coaching placements (including the formative assessment process) had changed their coaching practice, the findings additionally indicate how the students perhaps demonstrated some of the key skills considered to be lacking by the UK coaching sector and the sector skills councils. Examples of such skills can be seen in the remarks of how the students were "realising strengths and weaknesses". Additionally, comments on "specific areas" where they "need to improve" or how they felt they could "experiment" demonstrate how a more independent approach was undertaken. A more specific example in this fashion is the fact that they had to "plan to deliver sessions appropriate to the participants" and they were "developing a sense of their self-analytical roles". Since problem solving, team working, initiative and planning are part of the significant skills gaps identified within the UK for the coaching sector, and certainly form the basis for what many employers need, it is reasonable to assume that the findings generated here reflect how the modules may well be developing these skills outside of what can be considered traditional, campus based, learning.

Nevertheless, as noted in the beginning of the paper, there is a nuance that needs to be recognised in the use of using coaching placements in the university sector. What is of note is that students are not just learning how to coach, but additionally how to develop work-like attributes such as leadership, time management and working with others. So perhaps the most significant element of the findings relates to what the students picked up from the people they were working with - professional or volunteer coaches, invariably those that were older, more experienced and well versed in professional practice.

Examples of this include students stating that they "didn't have a choice about turning up on time - they did, so I knew I had to", how one "thought about how I need to present myself to people not from university", another "learnt that I need to be punctual, arrive 
early, finish late" and how they were "forced to work with others, a good thing - I picked up some really good habits".

This paper has referred to the use of formal, non-formal and informal learning and this reflects the fact that much of the existing research related to coach learning leans heavily upon this interpretation/framework (Cushion et al., 2010). Nonetheless, it could be argued that the findings for this paper are not fully explained by this existing body of research which emphasises and assumes a direct, willing engagement with learning.

To help us interpret the findings however there is also what is known as 'incidental' learning. Developed more through the fields of management, organisational and human resource studies, it is ostensibly still an element situated within informal learning. It does, however, have a caveat in that it refers to the manner in which learning takes place as a by-product of other activities - in particular through social situations and interaction between co-workers (Marsick and Watkins, 1990; Le Clus, 2011; Hyams and Sadique, 2014). In short, learners may not be conscious of their learning, in part explained by the way in which the learning was unintentional and as such, incidental (Foley, 2004; Von Treuer et.al., 2011). What is evident from the findings was that the students were influenced, in a context outside of university, by others. This influence extended their approach to professional practice and meets, in a broad fashion, many of the requirements for increased skills within coaching alongside wider work based ones.

\section{Conclusion: the value of coaching placements in developing industry skills}

In many respects this paper has suggested that there are three interlinked factors that should underpin HE provision in sports coaching outside of what might be considered the elite or performance pathway. The first factor, that government led attitudes and policy decisions favour up-skilling the broader workforce and a drive for employability, is supplemented by the second factor, the broad industry specific call for team working, communication, technical and practical skills, sport specific skills, and problem solving (SkillsActive, 2009; SkillsActive, 2010a; SkillsActive, 2010b). Because of the interlinked nature of the first and second factors, the third factor, the university sector's responsibility to facilitate work experience that is either sought or expected from graduate applicants, 
should essentially be a product of the interface of the first and second factors. However, and perhaps most significantly, what is of most importance is that the HE sector needs to ensure that the net result of their approaches to teaching and learning ends up allowing students to demonstrate the effective, noticeable and evident skills that they have learnt in the 'classroom' or other learning environment.

The author acknowledges that using just one HE institution and a relatively small sample size are limitations of the study. Additionally, using cohorts from different sports coaching courses would present a wider field from which to better understand how best students learn in a coaching context. Yet from the evidence presented, it might be fair to say that the research undertaken here has shown that the coaching placements completed by the students have had, admittedly from just the student perspective, a significant impact on their learning and performance. Overall, this can be shown by their ability to either understand, or indeed demonstrate, a number of the skills identified by SkillsActive. In addition to this, a particularly important feature of the student perspectives was the fact that they appreciated the context of experiential learning in comparison to more traditional, campus based learning. Furthermore, the facilitated work experience placements seemed to have had tangible benefits in terms of addressing preferential learning styles for the students themselves.

What is perhaps of most note, however, is that the evidence also paints a picture whereby students can learn in an unplanned fashion through others who are more experienced. And notably, who are already operating with work-like professional competency and practice. This last comment can be explained through using the concept of incidental learning. Whilst this is a concept that is cached within existing notions of coach education through informal learning, it nevertheless can be used here in a fashion that suggests that some developmental processes within coach learning are best facilitated unintentionally yet purposefully - through a wide range of experiences and activities outside of university experience.

Whilst the author is hesitant in trying to simplify the findings and suggestions of the paper in contrast to existing notions of coach education, it is their belief that the paper positions that an argument for a more informal, yet facilitated, learning strategy appears to have been developed - and that the findings and use of incidental learning are complementary 
to our understanding. If this is the case, then in order to construct a successful model that has employability at its core, the goal of HE sports coaching courses that look to develop more vocational, participation led outcomes should use - and emphasise - facilitated work experience type modules.

\section{References}

Amis, J. (2005) 'Interviewing for case study research', in Andrews, D. L., Mason, D. S. and Silk, M. L. (eds.) Qualitative methods in sports studies. Oxford: Berg Publishers, pp. 104-138.

BIS (Department for Business Innovation and Skills) (2010) Skills for sustainable growth, strategy document: full report, Department for Business Innovation and Skills. Available at:

https://assets.publishing.service.gov.uk/government/uploads/system/uploads/attach ment data/file/140059/bis-10-1274-skills-for-sustainable-growth-strategy.pdf (Accessed: 30 April 2018).

BIS (Department for Business Innovation and Skills) (2016) Success as a knowledge economy: teaching excellence, social mobility and student choice, Department for Business Innovation and Skills, May. Available at:

https://assets.publishing.service.gov.uk/government/uploads/system/uploads/attach ment data/file/523546/bis-16-265-success-as-a-knowledge-economy-web.pdf (Accessed: 20 April 2018).

Browne, J. (2010) Securing a sustainable future for higher education: an independent review of higher education funding and student finance, Department for Business, Innovation and Skills, October. Available at:

https://www.gov.uk/government/publications/the-browne-report-higher-educationfunding-and-student-finance (Accessed: 20 April 2018).

Byl, E., Struyven, K., Meurs, P., Abelshausen, B., Lombaerts, K., Engels, N. and Vanwing, T. (2015) 'Peer assisted learning as a tool for facilitating social and academic 
integration', Journal of Learning Development in Higher Education, Special Edition: Academic Peer Learning, November, pp. 1-28.

Cox, E. (2005) 'Adult learners learning from experience: using a reflective practice model to support work-based learning', Reflective Practice, 6(4), pp. 459-472. https://doi.org/10.1080/14623940500300517

Crotty, M. (2004) The foundations of social research: meaning and perspective in the research process. London: Sage Publications.

Cushion, C., Nelson, L., Armour, K., Lyle, J., Jones, R., Sandford, R. and O'Callaghan, C. (2010) Coach learning and development: a review of literature, SportsCoachUK, January. Available at: https://www.ukcoaching.org/sites/default/files/CoachLearning-and-Dev-Review.pdf (Accessed: 20 April 2018).

DfES (Department for Education and Skills) (2003) The future of higher education, Department for Education and Skills, White Paper, January. Available at: http://webarchive.nationalarchives.gov.uk/20040117000548/http://www.dfes.gov.uk/ highereducation/hestrategy/ (Accessed: 30 April 2018).

Deeley, S.J. (2014) 'Summative co-assessment: a deep learning approach to enhancing employability skills and attributes', Active Learning in Higher Education, 15(1), pp. 39-51. https://doi.org/10.1177/1469787413514649

DfE (Department for Education) (2017) Widening participation in higher education, England, 2014/15 age cohort, Department for Education, August. Available at: https://www.gov.uk/government/uploads/system/uploads/attachment data/file/6351 03/SFR39-2017-MainText.pdf (Accessed: 24 October 2017).

Driska, A. P. and Gould, D. R. (2014) 'Evaluating a problem-based group learning strategy for online, graduate-level coach education', Kinesiology Review, 3(4), pp. 227-234. https://doi.org/10.1123/kr.2014-0061 
ESECT (Enhancing Student Employability Coordination Team) (2006) Higher Education Academy learning and employability guide series 1: pedagogy for employability, Higher Education Academy, April. Available at:

https://www.heacademy.ac.uk/knowledge-hub/pedagogy-employability (Accessed: 30 April 2018).

Foley, G. (2004) 'Introduction: the state of adult education and learning', in Foley, G., (ed) Dimensions of adult learning: adult education and training in a global era. Maryborough, Victoria: Allen and Unwin, pp. 3-18.

Ford, N., Thackeray, C., Barnes, P. and Hendrickx, K. (2015) 'Peer learning leaders: developing employability through facilitating the learning of other students', Journal of Learning Development in Higher Education, Special Edition: Academic Peer Learning, November, pp. 1-23.

Gibbs, G. (2012) Implications of 'dimensions of quality' in a market environment, Higher Education Academy. Available at: https://www.heacademy.ac.uk/system/files/resources/HEA Dimensions of Quality 2.pdf (Accessed: 20 April 2018).

Gilbert, W. and Trudel, P. (2001) 'Learning to coach through experience: reflection in model youth sport coaches', Journal of Teaching in Physical Education, 21(1), pp. 16-34. https://doi.org/10.1123/itpe.21.1.16

Gilbert, W., Côté, J. and Mallett, C. (2006) 'Developmental paths and activities of successful sport coaches', International Journal of Sport Science and Coaching, 1 (1), pp. 69-76. https://doi.org/10.1260/174795406776338526

Gilbert, W. and Trudel, P. (2006) 'The coach as a reflective practitioner', in Jones, R. L. (ed.) The sports coach as educator: reconceptualising sports coaching. London, Routledge, pp. 114-127. 
GOV.UK (UK Government) (2018) 'What qualification levels mean'. Available at: https://www.gov.uk/what-different-qualification-levels-mean/list-of-qualificationlevels (Accessed: 30 April 2018).

Gratton, C. and Jones, I. (2010) Research methods for sports studies. $2^{\text {nd }}$ edn. London: Routledge.

Green, M. and Houlihan, B. (2005) Elite sport development: policy learning and political priorities. London: Routledge.

Groves, M., Bowd, B. and Smith, J. (2010) 'Facilitating experiential learning of study skills in sports students', Journal of Further and Higher Education, 34(1), pp. 11-22. https://doi.org/10.1080/03098770903477060

Hafford-Letchfield, T. and Bourn, D. (2011) "How am I doing?': advancing management skills through the use of a multi-source feedback tool to enhance work-based learning on a post-qualifying post-graduate leadership and management programme', Social Work Education, 30(5), pp. 497-511. https://doi.org/10.1080/02615479.2010.505263

HEFCE and OFFA (Higher Education Funding Council for England and Office for Fair Access) (2014) National strategy for access and student success. London: Department for Business, Innovation and Skills. Available at: http://www.hefce.ac.uk/sas/nsass/ (Accessed: 1 October 2017).

Higher Education Academy (2016) Framework for embedding employability in higher education, Higher Education Academy. Available at: https://www.heacademy.ac.uk/system/files/downloads/embedding-employability-inhe.pdf (Accessed: 30 April 2018).

Hyams, R. and Sadique, D. (2014) 'The value of incidental learning in a multidisciplinary setting', International Journal of Clinical Legal Education, 20(1), pp. 439-460. 
Irwin, G., Hanton, S. and Kerwin, D.G. (2004) 'Reflective practice and the origins of elite coaching knowledge', Reflective Practice, 5(3), pp. 425-442.

https://doi.org/10.1080/1462394042000270718

Jones, R. L, Armour, K. M. and Potrac, P. (2004) Sports coaching cultures: from practice to theory. London, Routledge.

Jones, R. L. (2006) 'How can educational concepts inform sports coaching?', in Jones, R. L. (ed.) The sports coach as educator: re-conceptualising sports coaching. London, Routledge, pp. 3-13.

Kennedy, H. (1997) Learning works: widening participation in further education. Coventry: The Further Education Funding Council.

Kovacs, L. and Corrie, S. (2017) 'Building reflective capability to enhance coaching practice', The Coaching Psychologist, 13(1), pp. 4-12.

Knowles, Z., Borrie, A. and Telfer, H. (2005) 'Towards the reflective sports coach: issues of context, education and application', Ergonomics, 48(11-14), pp. 1711-1720. https://doi.org/10.1080/00140130500101288

Le Clus, M. A. (2011) 'Informal learning in the workplace: a review of the literature', Australian Journal of Adult Learning, 51(2), pp. 355-373.

Lord Robbins (1963) Higher education: report of the committee appointed by the Prime Minister under the chairmanship of Lord Robbins. London: Her Majesty's Stationery Office. Available at: http://www.educationengland.org.uk/documents/robbins/robbins1963.html

Lyle, J. (2002) Sports coaching concepts: a framework for coaches' behaviour. Abingdon: Routledge.

Lynch, C. (2010) Doing your research project in sport. Exeter: Learning Matters Ltd. 
LSRC (Learning and Skills Research Centre) (2004) Should we be using learning styles? What research has to say to practice. London: Learning and Skills Research Centre.

Maher, A. (2005) Embedding employability in the curriculum: enhancing students career planning skills, Higher Education Academy and the Hospitality, Leisure, Sport and Tourism Network. Available at: https://www.heacademy.ac.uk/knowledgehub/embedding-employability-curriculum-enhancing-students-career-planning-skills (Accessed: 21 April 2018).

Marsick, V. J. and Watkins, K. (1990) Informal and incidental learning in the workplace, London: Routledge.

Massey, A. (2010) Higher education in the age of austerity part two: shared services, outsourcing and entrepreneurship. London: Policy Exchange. Available at: https://www.bl.uk/collection-items/higher-education-in-the-age-of-austerity-sharedservices-outsourcing-and-entrepreneurship (Accessed: 27 April 2018).

Minten, S. and Foster, W. (2009) 'Enhancing graduate employability in sport', in Bill, K. (ed.) Sport Management. Exeter: Learning Matters, pp. 21-33.

National Occupational Standards (2016) What are national occupational standards? Available at: https://www.ukstandards.org.uk/Pages/index.aspx (Accessed: 20 April 2017).

OFFA (Office for Fair Access) (2015) Strategic Plan: 2015-2020. Available at: https://www.offa.org.uk/wp-content/uploads/2015/03/OFFA-Strategic-Plan-20152020.pdf (Accessed: 20 April 2017).

Palermo, C., Chung, A., Beck, E.J., Ash, S., Capra, S., Truby, H. and Jolly, B. (2015) 'Evaluation of assessment in the context of work-based learning: qualitative perspectives of new graduates', Nutrition \& Dietetics, 72(2), pp. 143-149. https://doi.org/10.1111/1747-0080.12126 
Pegg, A., Waldock, J., Hendy-Isacc, S. and Lawton, R. (2012) Pedagogy for employability update, Higher Education Academy. Available at:

https://www.heacademy.ac.uk/system/files/pedagogy for employability update 20 12.pdf (Accessed: 21 April 2018).

QAA (The Quality Assurance Agency for Higher Education) (2014) Employer engagement: emerging practice from QAA reviews, Quality Assurance Agency for Higher Education. Available at:

http://www.qaa.ac.uk/en/Publications/Documents/Employer-Engagement-Report.pdf (Accessed: 17 October 2017).

Rubin, H. J. and Rubin, I. S. (1995) Qualitative interviewing: the art of hearing data. London: Sage.

Schön, D. A. (1983) The reflective practitioner: how professionals think in action. New York: Basic Books.

Schön, D. A. (1987) Educating the reflective practitioner. San Francisco: Jossey-Bass Publishers.

scUK (Sports Coach UK) (2009) Draft criteria for endorsement of foundation degree and undergraduate courses in sports coaching. Leeds; scUK. (This document is no longer available online).

scUK (Sports Coach UK) (2011) Coaching children curriculum, Sports Coach UK. Available at: https://www.ukcoaching.org/sites/default/files/Coaching-ChildrenCurriculum.pdf (Accessed: 21 April 2018).

Shepherd, M. (2006) 'Using a learning journal to improve professional practice: a journey of personal and professional self-discovery', Reflective Practice, 7(3), pp. 333-348. https://doi.org/10.1080/14623940600837517

SkillsActive (2009) Skills priorities for active leisure, learning and well-being: UK summary. London: SkillsActive. 
SkillsActive (2010a) Sector skills assessment active leisure, learning and well-being:

Wales summary report. London: SkillsActive. Available at:

http://www.skillsactive.com/PDF/Sector Skills Assessment Summary.pdf

(Accessed: 21 April 2018).

SkillsActive (2010b) Sector skills assessment 2011: UK report. London: SkillsActive.

SkillsActive (2018) Higher education endorsement for sports coach education. Available at: http://www.skillsactive.com/endorsement/higher-education-endorsement-forsports-coach-education (Accessed: 30 April 2018).

Student Funding Panel (2015) An analysis of the design, impact and options for reform of the student fees and loans system in England. London: Universities UK. Available at: http://www.universitiesuk.ac.uk/policy-andanalysis/reports/Documents/2015/student-funding-panel.pdf (Accessed: 21 April 2018).

Taylor, B. and Garratt, D (2008) The professionalisation of sports coaching in the UK: issues and conceptualisation. Leeds: Sports Coach UK. Available at: https://www.ukcoaching.org/sites/default/files/professionalisation-of-sportscoaching.pdf

Taylor, B. and Garratt, D. (2010) 'The professionalisation of sports coaching: definitions, challenges and critique', in Lyle, J. and Cushion, C. (eds.) Sports coaching: professionalisation and practice. Edinburgh: Elsevier, pp. 99-118.

Thurgate, C. and MacGregor, J. (2009) 'Students' perceptions of undertaking workplace tasks within a foundation degree - health and social care', Assessment \& Evaluation in Higher Education, 34(2), pp. 149-157.

https://doi.org/10.1080/02602930801956893 
Turner, D. and Nelson, L. J. (2009) 'Graduate perceptions of a UK university based coach education programme, and impacts on development and employability', International Journal of Coaching Science, 3(2), pp. 3-28.

UKCES (UK Commission for Employment and Skills) (2012) Hospitality, tourism and sport sector: sector skills assessment 2012, UK Commission for Employment and Skills, Briefing Paper, October. Available at:

https://www.gov.uk/government/publications/hospitality-tourism-and-sport-sectorskills-assessment (Accessed: 21 April 2018).

Universities UK (2017) Degree apprenticeships: realising opportunities. London:

Universities UK. Available at: http://www.universitiesuk.ac.uk/policy-andanalysis/reports/Pages/degree-apprenticeships-realising-opportunities.aspx (Accessed: 21 April 2018).

Von Treuer, K., Sturre, V., Keele, S. and Mcleod, J. (2011) 'An integrated model for the evaluation of work placements', Asia-Pacific Journal of Cooperative Education, 12(3), pp.195-204. Available at:

https://www.ijwil.org/files/APJCE 123195 204.pdf (Accessed: 19 April 2018).

\section{Author details}

Philippe Crisp is a Senior Lecturer in the Institute of Sport, University of Chichester. 